\title{
The Empowerment of Social Media for Da'wah in Medan City
}

\author{
Ali Murthado \\ Ph.D Student at State Islamic University of North Sumatra (UINSU) Medan, Indonesia \\ Lecturer at State Islamic University of North Sumatra (UINSU), Medan, Indonesia
}

\begin{abstract}
Islam as a responsive religion to all changes and circumstances, it is proper to evaluate its traditional da'wah. Traditional da'wah is a preaching with the use of oral media (dakwah bil lisan). But it should be able to develop the means of da'wah in the wide area (not just sermons or lectures) but must be able to penetrate the cyber world in order to sow the seeds of Islam. Da'wah using internet is often called the eda'wah or electronic da'wah, where through electronic media in this case internet, da'wah is hoped to be more developed and more distinctive color, especially for the internet users. preachers should be able to choose another strategy that is by preaching through social media which is much in demand by today's youth. That is why da'wah through oral is still being done added with da'wah through social media. A preacher should be able to empower themselves to develop da'wah through social media. Da'wah which is through social media has certainly many advantages for especially the preachers. Besides for the preachers, the advantages also can be for the users of social media. Social media users can access freely without any limit of time and place.
\end{abstract}

Keywords: Al Quran; da'wah; social media; negative and positive impact

\section{INTRODUCTION}

Da'wah (preaching) is a way that must be traveled in order to enforce izzul Islam wal-muslimin (the glory of Islam and its followers). Like the two images on a coin, $d a$ 'wah and Islam cannot be separated. Where there is Islam there is da'wah grows. Da'wah is not just a process, but da'wah is an obligation from Allah as revealed in Surah An-Nahl verse 125:

Meaning:

Invite to the way of your Lord with wisdom and good instruction, and argue with them in a way that is best. Indeed, your Lord is most knowing of who has strayed from His way, and He is most knowing of who is [rightly] guided. ${ }^{1}$

It is so noble and general the position of $d a^{\prime} w a h$ in Islam, so it has become imperative for every individual Muslim who claims not only be called but try to devote his life to preach. Along with the rapid growth of the time, a few years ago appeared in front of us a "new world" together with the presence of internet. Man with his cleverness managed to create a world without distance and insulation through internet. Internet has also managed to connect people among other in just seconds. Some countries can turn our visit in a short time. Besides the real world that we are facing every day, we are also presented an "other world" which is often mentioned as cyber world or virtual world. Along with this, Islam as a responsive religion to all changes and circumstances, it is proper to evaluate its traditional $d a^{\prime}$ 'wah. Traditional $d a$ 'wah meant here is a preaching with the use of oral media (dakwah bil lisan). But it should be able to develop the means of da'wah in the wide area (not just sermons or lectures) but must be able to penetrate the cyber world in order to sow the seeds of Islam. Da'wah using internet is often called the $e-d a$ 'wah or electronic da'wah, where through electronic media in this case internet, da'wah is hoped to be more developed and more distinctive color, especially for the internet users.

The purposes of da'wah are people believe in Allah and live along with His religions values. Although we have to realize that not all the purposes of da'wah will be achieved because of hidayah is a gift from Allah SWT. So, whatever we do hard much more we convey the truth and touch the people's heart to live with the values as He wishes, their success lies on Allah's hand. Allah reminds us in His saying in Surah Ar-Ra'd: 31. Meaning:

\footnotetext{
${ }^{1}$ Depag RI, Al-Qur'an dan Terjemahnya (Semarang: CV. Toha Putra, 1989),p 413.
} 
And if there was any Qur'an by which the mountains would be removed or the earth would be broken apart or the dead would be made to speak, [it would be this Qur'an], but to Allah belongs the affair entirely. Then have those who believed not accepted that had Allah willed, He would have guided the people, all of them? And those who disbelieve do not cease to be struck, for what they have done, by calamity - or it will ${ }_{2}$ descend near their home - until there comes the promise of Allah. Indeed, Allah does not fail in [His] promise.

In Surah Yunus: 99 Allah SWT says:

Meaning:And had your Lord willed, those on earth would have believed - all of them entirely. Then, [O Muhammad], would you compel the people in order that they become believers?

Each Muslim has a task to explain the fact and ask people to accept the truth of Islam teachings. Whether it is accepted or not of the da'wah lies on themselves. As Allah SWT says in Surah Al Baqarah: 256. Meaning There shall be no compulsion in [acceptance of] the religion. The right course has become clear from the wrong. So whoever disbelieves in Taghut and believes in Allah has grasped the most trustworthy handhold with no break in it. And Allah is Hearing and Knowing. ${ }^{3}$

This verse explains that there is no reason that justifies forcing people to believe and become Muslims, or to ask them to fulfill the obligations as a Muslim and stay away from sin. We can only advise. Besides, every Muslim should avoid harsh attitude, angry and aggressive. All these behaviors arise due to the lack of knowledge and understanding of Qur'an. We must cultivate the values of moderate, gentle, tolerant, calm and suave as depicted Allah SWT in Qur'an. Only with maturity, tolerance, moderation, and peace, Muslims are able to be an example to the world and have a positive impact on the values of Islam. The adult attitude, tolerant, moderate, calm should be the method of da'wah.

\section{METHODOLOGY}

As explained earlier that in this study there are three theories emerged: firstly: uses and gratification theory. This theory is not interested in what the media do to people but more interested in what people do to media. Uses and Gratification tends to use the approach which focused on "why do a group of people choose to use a particular media rather than the actual content offered". This approach is in contrast to compare the effects of media and not the 'what media do people (which focuses on homogeneity of the people in mass communication and see the media as a hypodermic needle).People or audiences are considered actively use media to meet their gratification. They actively and selectively receive the exposure/messages from the mass media that come to them and they do not want to just accept all the exposure. People are actively in selective exposure. Selective exposure means that the people chose the mass media and the message content that they believe is the most appropriate to their views, opinions and experiences. People will use the mass media which is useful for them and will tend to avoid the media that is useless for them. Therefore this theory (Uses and Gratification) focuses on the media uses to get gratification on the public needs. Uses and gratification theory tries to see that the uses of social media is mostly done by the so-called 'native digital' although it is possible for the so-called 'immigrant digital'. That is why the theory is also used to examine how far the uses of social media in interactions to Islam.

Figure1. The Selection of Chosen Media

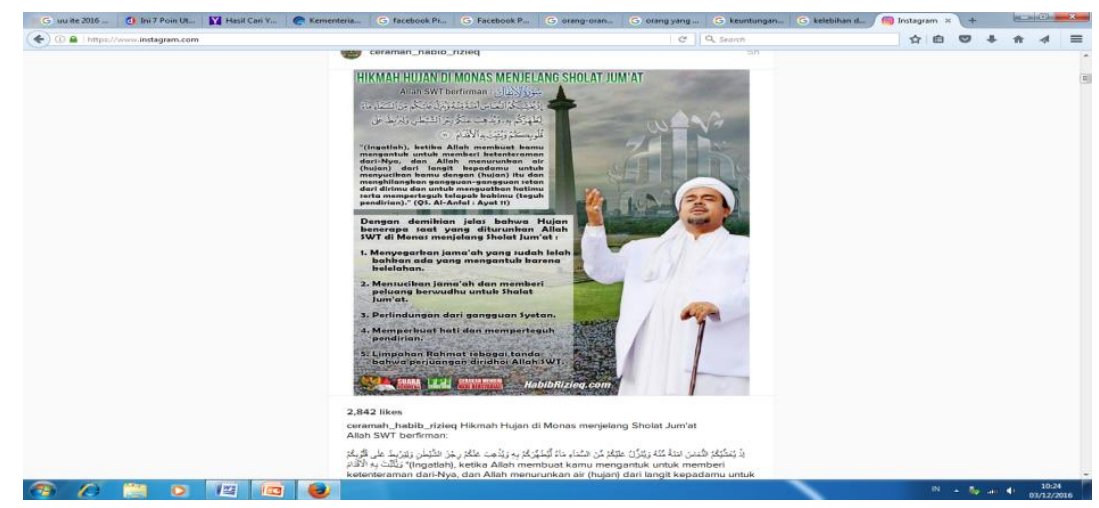

${ }^{2}$ Depag RI, Al-Qur'an ..p 366.

${ }^{3}$ Ibid., p. 59. 


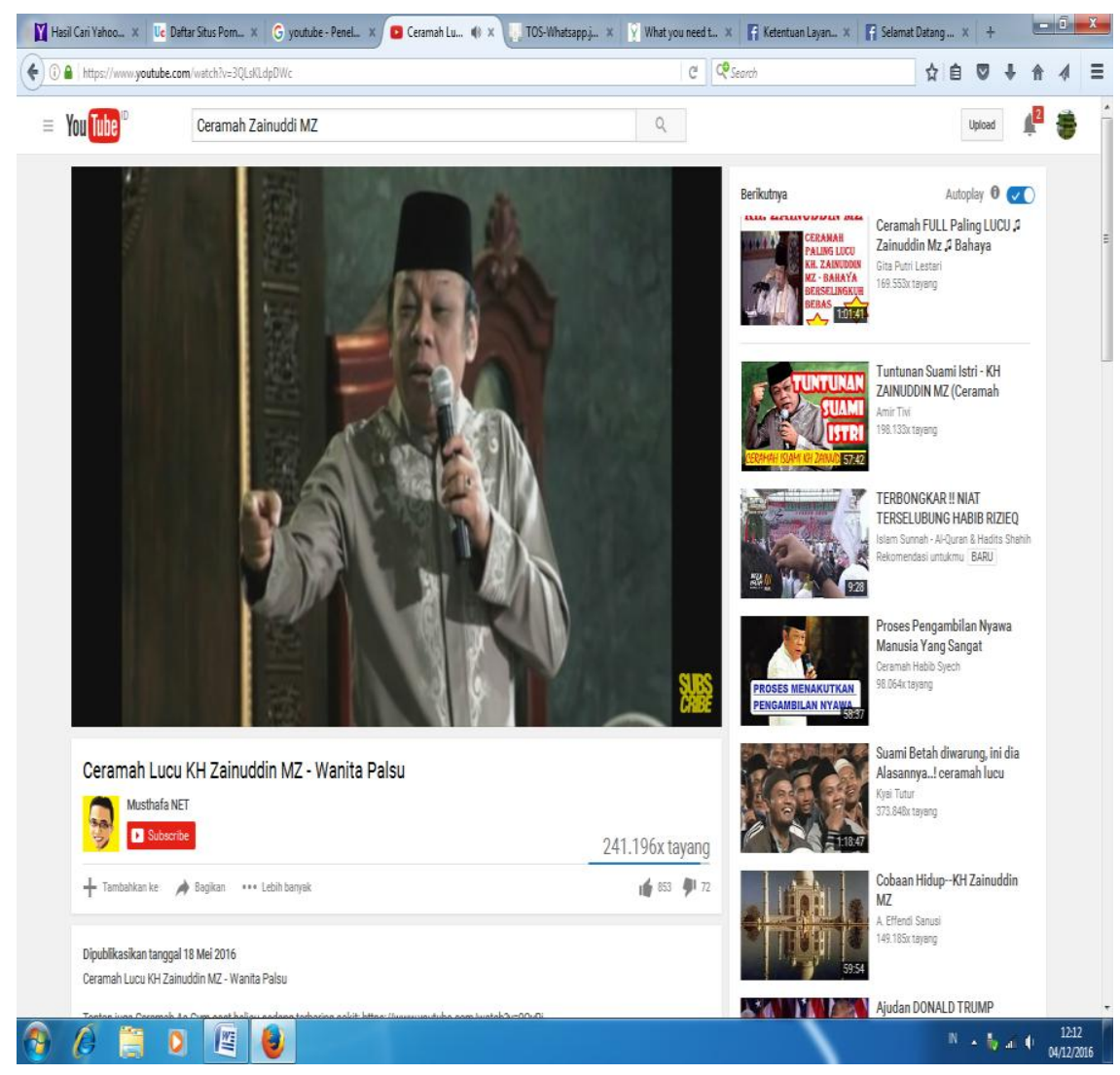

Furthermore, this theory explains that the media users play active roles in selecting and using these media, in other words, the media users are active party in the communication process. As an example of social media, users choose freely in using social media whether by using Facebook, WhatsApp, Twitter, Youtube and Instagram. The selection made by the users depend on their capacities to use the social media. If they feel that facebook is chosen to be a means of da'wah then nothing can hold them. Likewise, if they chose WhatsApp, Twitter, Youtube and Instagram. This means that with their uses and gratification theory there are choices for the users. Media users try to find a good source of best media in an effort to meet their needs. It means that the uses and gratification theory assumes that users have alternative options to satisfy the needs.

Second, this study also uses the theory of social change, meaning that through the fact there is a da'wah media that can change because of the existing development. If the first $d a{ }^{\prime} i$ and $d a$ 'iah more highlighted the da'wah of bil lisan, then in the presence of social media, da'wah can be done at home, in the office or even while shopping or on vacation to a certain area. Everyone thinks and agrees that social life is not static and is always dynamic. But not everyone interprets the same in interpreting social change. Social change is considered as a phenomena and become problematic until now. The change is a nature law called sunnatullah. The social changes of course are permissible, as long as they do not violate the social principles that have been established by Allah. Allah SWT says:

Meaning:For each one is successive [angels] before and behind him who protect him by the decree of Allah. Indeed, Allah will not change the condition of a people until they change what is in themselves. And when Allah intends for a people ill, there is no repelling it. And there is not for them besides Him any patron. ${ }^{4}$

These changes are to be followed by the $d a$ ' $i$ and $d a$ 'iah so that they are not considered outdated. If the preacher only preaches through oral, then only the old people hear the messages, because it is difficult to ask teenagers be invited to the mosque to listen to the preachers' sermons. Then do the preachers have to force themselves to preach to them or have to choose a different one? Then the preachers should be able to choose another strategy that is by preaching through social media which is much in demand by today's youth. That is why da'wah through oral is still being done added with da'wah through social media. A preacher should be able to empower themselves to develop da'wah through social media. This what da' $i$ and da'iah do in Jakarta, such as KH Arifin Ilham, KH Abdullah Gymnastiar, Ustaz Yusuf Mansur and many other preachers who have used social media to means of their da'wah, whether by using facebook, twitter, WhatsApp, Youtube and Instagram.

${ }^{4}$ Depag RI, Al-Qur'an.., p. 362 
This study also uses mediamorfosis theory. The concept of morfosis media is introduced by Roger Fidler, director of Knight Ridder on New Media, in 1990 in his article about the future of newspapers. Roger Fidler is recognized internationally as a pioneer and visioner of news media. He is known for his vision on a digital newspaper and mobile reading devices, in 1981. In 1994, his team at the lab produced a video entitled "The Tablet Newspaper: A Vision for the Future" which shows how people might one day read newspapers and magazines in the tablet. ${ }^{5}$

Mediamorfosis is derived from the word "mediamorphosis" which means transformation' of communication media, usually as a result of a complex interplay of imaginable needs, competitive and political pressures and social and technological innovations. ${ }^{6}$ Mediamorfosis theory actually is a theory that sees the development of mass media. AM radio which is not completely submerged due to the emergence of FM radio, and instead adopts a new marketing strategy and technology, shows the key principles of mediamorfosis. Another example is when TV, radio, newspapers, magazines and movies got hit hard. But in fact, each of them is proven to be resilient and able to adapt. This illustrates an important corollary in the mediamorfosis principle that is the form of communication exist must be changed in facing the emergence of new media unless the only option is death. ${ }^{7}$

\section{DISCUSSION}

Regardless of the pros and cons of social media presence, social media can be used as the revitalization of social relationships among the users. Social media can be a place to meet virtually to family, friends, or colleagues that separated by distance and time. Social media can be a 'home' or 'space' for interaction with one another. The presence of social media gives opportunities for every individual to be the sender and receiver. Only by having access to cyberspace, then creating an account on a social media service provider, every individual has one-to-many media. The presence of unpaid social media which is now various widely, make the use of social media becomes a common practice. Without requiring any special skill of programming languages, social media utilization becomes user friendly. So that almost all people become familiar with this social media.

Coffee shop owner can update the status that at 13:00 the shop is open, a primary school student can update his playing ball status, the artist can give criticism of government policies, there are certain figures who give information related to the government that are rarely reported in the media, politicians can also extend their aspirations nets, soccer players can perform fan meeting, and various other circles. The high technology of social media in the convergence of media, hypertext, and simulation makes social media is increasingly in demand. Even mobile application for social media makes everyone can use it anywhere by having a mobile phone network as along as connected with internet or internet packages.

Many things can be done on social media as described above. At least until the current technological developments allow the user's presence in social media is still limited to only a representation of himself (sometimes it is used the term of virtual self, digital me, me virtual, virtual identity), but it has not reached at the level of totality in the social media.

Besides that, social media can also be used as a means to preach, especially today da'wah must be done in a various things that surround the reality and innovations that are suited to the times. The concept of $a l$ Islamu sholih likulli zaman wa makan (Islam is suitable with the conditions of time and place) is a principle that must be held by da'i in carrying out his duty. The beauty of Islam explicitly and implicitly beautiful in Qur'an and hadith only will be a sign of God's "hidden" power if it cannot be understood and practiced in da'wah $m^{\prime} d^{\prime} u$. Access and understanding towards the sources of technologies need to be considered for the da' $i$. The communicators Islam need not only religion knowledge, and general knowledge to compile Islamic contents, but also the media which is an effective tool in performing the noble task of da'wah. One of the technologies in society that becomes a trend today is the internet.

Specifically, Huntington in Clash of civilization speaks plainly about the power of Western and nonWestern. In doing the ways of mastering a nation, can use two forms of power, they are the hard power and soft power. Hard Power is the ability of the state to take a policy that relies on economic and military power. While the meaning of Soft power is the ability of the state to make other countries choose their desire accordance with the wishes of the country through their culture and ideology. In this sense, information and communication technologies can be hard power and soft power tool at the same time. This is because in the information and communication technology, media content issues have an impact on the ways people behave. In this condition, Schiller stated that there is no doubt information technology including the Internet has produced a lot of information that has never happened before. There is no doubt also that technology produces, stores, accesses,

${ }^{5}$ Lihat Rjionline.org. Roger Fidler (2013), from http://www.rjionline.org/people/roger-fidler downloaded on 29 November 2016.

${ }^{6}$ Roger Fiddler, Mediamorfosis (Yogyakarta: Bentang Budaya, 2003), p. 35

${ }^{7}$ See https://id.wikipedia.org/wiki/Mediamorfosis 
process and disseminates the information. If only a da'i or Islamic organizations in Medan City were able to empower the facilities available in social media da'wah could be done among young people who are very close to the social media.

Feri Sulianta states that the effective and efficient promotion in the reform era is a collaboration of various online services, such as the use of blogs, discussion forums, chat rooms, emails, webistes, and also the power of social networking community. If you would like to promote in the 21 st century, the companies must promote by following the activities of the society ways in this century.

Picture: Ustaz Yusuf Mansur's Instagram

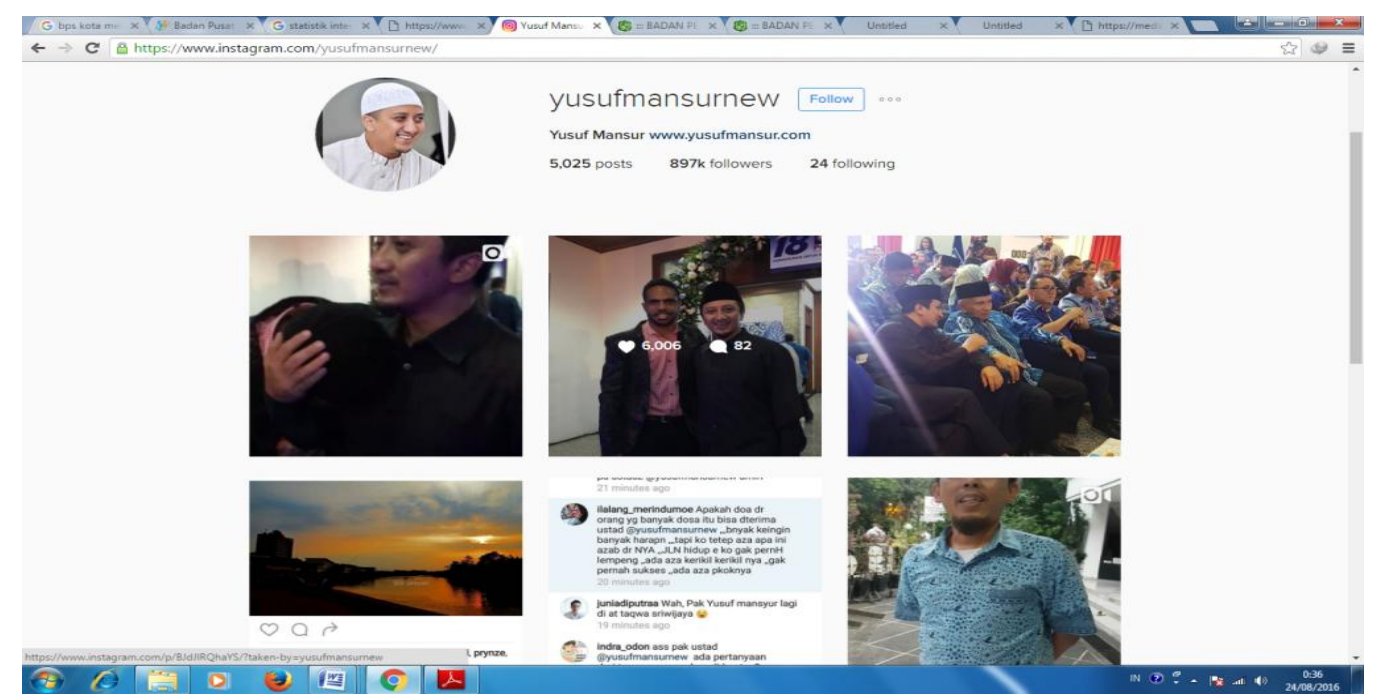

Via his Instragram, Yusuf Mansur besides uploading his photos of activities, he also videotaped what he did when he was in his home, at his Islamic school, and other activities. In his videos, he does not forget to insert da'wah invitations whether about the charity, always pronounce blessings on the Prophet Muhammad PBUH and others. There are 897 followers and 5025 posts which he shared whether they are in the form of pictures or videos on his Instagram yusufmansurnew. Besides that many of his lectures also uploaded on Youtube so that it is easy for us to hear the content of his lectures.

Likewise with Rizieq who uses social media of Youtube to spread his da'wah to the middle of the community. Although not all the contents of his video lectures uploaded by himself. But at least what he speaks in his lectures certainly provide lessons for those who really want to hear the contents of a lecture from the Chairman of the Islamic Defenders Front (FPI). From there we can see what actually happening is with FPI activities if they are wrong in taking action or on the contrary before they act first, they make efforts of legal approach.

In the era of information technology today, the role of news media and social media in $d a$ 'wah is very important. Da'wah is not only performed in the mosque, but can also in the internet. Today, the public needs for information become main need. In the old time people only got the information when he often read the newspaper, watched the news on television and listened to the radio. However, because of busy daily activities, then many people who work do not have time to watch television and read newspapers to get information. But they have alternatives to get the information that is by accessing the Internet via cell phone.

The information obtained is without being in space and time, which means that whenever needed it will be there. Of course, this is a golden opportunity for $d a$ ' $i$ to use the Internet as a medium of da'wah. Besides preaching through the real world, the $d a$ ' $i$ also is needed to preach through the virtual world as a supporter of $d a$ 'wah in the real world. Because of remembering to preach through real world is highly dependent on space and time. Preaching by using social media has various forms of benefits. Although most people assume that preaching through social media requires a special time, but as more people access the internet then the da'wah is much wider than could be done. Da'wah by using social media such as facebook has been done by many da'i. The da'wah messages conveyed are various, from motivation to perform shalat, motivation about life, being tawadlu, respect for others, being grateful, and so forth. Preaching in social media such as twitter is also not left behind. As Felix Siauw did who is known as a da'wah activist in social media, because his messages on twitter are so popular, solid, steady and influential as well as touched the hearts of his followers. The number of his followers now reached 1.86 million people. See the twitter appearances of Felix Siauw, AA Gym, Habib Rizieq Shihab and KH Arifin Ilham below: 
Islam is a religion which often misunderstood because of one-sided reporting, biased, in many Western media. That is why e-da'wah or preaching through electronic media is very important to do the preachers. The Islamic da'wah should consider the change of this social landscape. The conventional Da'wah which relies on face-toface, need to be equipped with tele-da'wah (with the help of journalism and broadcasting), and e-Da'wah (with the help of information technology).

Some missions can be reached by e-da'wah. First, it extends the reach of da'wah, both geographically and da'wah that related to the audience. Currently, Muslims have spread throughout the world and become the fastest growing religion in the world, $2.9 \%$ per year. In 2050, as reported www.telegraph.co.uk, predicted that a fifth of European population is Muslim. Today, 25\% of the population in Marseilles and Rotterdam are Muslims, $20 \%$ in Malmo, $15 \%$ in Brussels and Birmingham and 10\% in London, Paris, and Copenhagen. In America, the development of Muslims is also very rapid that indicated, one of them is the number of mosques in the United States as 1,209 units. Other fact shows that because of various activities, especially in communities with norms and policies that are not familiar with Muslims, make many Muslims who cannot be physically present in the da'wah assembly. Muslim generations without this mosque - borrowing a term from Prof. Kuntowijoyo - need to be considered. In short, the use of the Internet for e-da'wah can traverse space and time.

Second, e-da'wah helps to show the true face of Islam. The bad image of Islam due to biased reporting by many Western media needs to be fixed. The most appropriate to fight against the media is with media as well. Internet offers the opportunity for it to provide facilities to spread the clear and correct ideas and messages of ilahiyah. This can be used as an initiative to provide information to non-Muslims friends. When Islam is blamed after WTC bombing on 11 September 2001, the popularity of the word "Islam" is outperform the word "porn" on searching sites on the Internet. We can imagine that if a friend who wants to know more about Islam, he will get the right and satisfying information about Islam on the Internet. Tens of thousands of Americans reportedly converted to Islam after the tragic bombing of the World Trade Center by finding out the correct information about Islam.

Third, e-da'wah in improving the image of Islam in the technological backwardness. The use of the Internet for da'wah also indicates that Muslims can adjust themselves to the existing civilization, as long as it does not conflict with aqidah. Islam must respond to the environmental developments, including technology wisely without being out of the true teachings. The new phenomenon of this century shows the rise of digital da'wah that develops as the development of information technology in the Internet. In this digital age "connectivity" has a broader meaning than just a place for two or more interconnected persons. Internet gives a new universal space to share information, to collaborate, and to interact. It is just left how Muslims in this case the da' $i$ and Islamic organizations to empower themselves into digital native costumers. Da'wah can also be performed through a blog and website. If a regular website only provides a "one-way communication," the visitors just accept what they read in the pages of the website without being able to comment on it (visitors become passive), while blogs provide a "two-way communication" on visitors. The published contents can be given and the comments can be replied by other visitors or owners of a blog (visitors become active). It will be more useful when the blogs are used for the purposes of da'wah, and so is the website if it is used as a medium of effective and efficient da'wah.

Among the examples of websites used for the benefit of the mission is yusufmansur.com belongs to Ustad Yusuf Mansyur. He uses language that is motivating and touching to always draw closer to Allah SWT. Ustadz Yusuf Mansur with his website wisatahati.net, as well as www.syariahbisnis.com and others tries to introduce Islamic rahmatan lil Alamin to the public. Fourth, new media with its software application can provide convenience in performing da'wah, Another thing we can use the advantage is in efficiency. If the physical books of hadith that are tens even hundreds, with the advancement of Information Technology are just stored in a computer/ flashdisk that is easy to carry and read anywhere. By doing digitized texts there have been widely available electronic books (e-books) that we can enjoy good books of tafsir, tarikh, books of hadith, fiqih books and others. These applications include digital Qur'an: to ease the searching for verses and topics in Alqur'an, Maktabah syamilah and others. Fifth, new media with mobile phone application can also be used for the purposes of da'wah. This is apparent from so many mobile phone users, from top class entrepreneurs to under the class entrepreneurs, even not few jobless youth, students who do not have any income use mobile phones. Seeing the use of mobile phones rampantly, then it will be beneficial if the mobile phone is used as a medium of da'wah, that is by using it as a medium to send the messages containing normative Islamic values. Sixth, the new media by electronic mail (e-mail) can ease and accelerate the access to any information anywhere and anytime. With the communication in the delivering of information, there is no limited distance and time. With the e-mails, people can deliver messages directly though a long distance. This is very effective and efficient in the development of Islamiyah da'wah. 


\section{CONCLUSION}

Da'wah which is through social media has certainly many advantages for especially the preachers. Besides for the preachers, the advantages also can be for the users of social media. Social media users can access freely without any limit of time and place. On the other hand, social media has a negative impact for the Internet user community. One example is social media can be easily imitated and misused by irresponsible person and this against da'wah teachings. Then da'wah through social media also may create misinterpretation. The understanding gained may likely is different from the real message delivered. This also cannot be separated from the role of the media as one-way communication only. If this happens continuously, it can eliminate the true meaning of the teachings. The interaction in da'wah becomes important for the preacher and the community. Da'wah directly is more interactive and efficient in delivering the preaching message,

\section{REFERENCES}

[1] Agama, Kementerian, Alquran \& Tafsirnya, Jilid I-X, Jakarta: Lentera Abadi, 2010.

[2] Ahmad, Fadil Ibnu. Dakwah Online, Bandung: Mizania, 2014.

[3] Antonio, Muhammad Syafii, Ensiklopedia Leadership \& Manajemen Muhammad SAW "The Super Leader Super Manager"; Manajemen Dakwah. Jakarta: Tazkia Publishing, 2010

[4] Anshari, Saifudin, Pokok-pokok Pikiran tentang Islam, Bandung: Pustaka Pelajar, 1969.

[5] Amin, M. Masyhur, Dakwah Islam dan Pesan Moral, Jakarta: Al amin Press, 1997.

[6] Amin, Samsul Munir. Ilmu Dakwah, Jakarta: Amzah, 2009.

[7] al-Baqi, Muhammad Fu'ad 'Abd, al-Mu'jam al-Mufahras li Alfaz al-Qur'an al-Karīm, Bairut: Dar alFikr, 1992.

[8] Afrizal, Metode Penelitian Kualitatif; Sebuah Upaya Mendukung Penggunaan Penelitian Kualitatif Dalam Berbagai Disiplin Ilmu, Jakarta: Rajawali Pers, 2014.

[9] 'Aqil, Bahaud Din Abdullah ibnu, Alfiyyah Syarah Ibnu 'Aqil (terjemahan) Bandung: Sinar Baru, 1992.

[10] Arifuddin, Acep, Pengembangan Metode Dakwah; Respons Da’i Terhadap Dinamika Kehidupan Beragama di Kaki Ciremai (Jakarta: Rajawali Pers, 2011),

[11] Arifin, Anwar, Dakwah Kontemporer Sebuah Studi Komunikasi Yogyakarta: Graha Ilmu, 2011.

[12] Arikunto, Suhasimi. Prosedur Penelitian, cet II, Jakarta : PT Bina Aksara, 1985.

[13] Aziz, Mohd. Ali, Ilmu Dakwah (Edisi Revisi), cetakan ke-4, Jakarta: Prenadamedia Group, 2015.

[14] As-Shanhaji, Muhammad, Al-Jurumiyah, Kairo, tp, $1324 \mathrm{H}$.

[15] Bharata, Addy Sukma dan Al Kalam. Ayo Buat Facebook-mu Menarik, Jakarta: Elex Media Komputindo, 2008.

[16] Basyaruddin. Peta Dakwah Kota Medan, Medan: Perdana Publishing, 2012.

[17] Bungin, Burhan Penelitian Kualitatif : Komunikasi, Ekonomi, Kebijakan Publik, dan Ilmu Sosial lainnya, cet. V, Jakarta: Kencana Prenada Media Group, 2011.

[18] Bungin, Burhan. Analisis Data Penelitian Kualitatif, Jakarta: PT.Grafindo Perkasa, 2003.

[19] Bharata, Addy Sukma dan Al Kalam, Ayo Buat Facebook-mu Menarik Jakarta: Elex Media Komputindo, 2008.

[20] Brogan , Cris, Social Media 101 Tactic and Tips to Develop Your Business Online. New Jersey: John Wiley \& Sons, Inc., 2010.

[21] Budiman, Kris. Semiotika Visual; Konsep, Isu dan Problem Ikonisitas Yogyakarta: Jalasutra, 2011.

[22] Devito, Joseph A.Komunikasi Antarmanusia; Kuliah Dasar.Jakarta: Professional Books, 1997.

[23] Dewan Redaksi Ensklopedi Islam, Ensklopedi Islam, Cet. 4, Jakarta: Ichtiar Baru Van Hoeve, 1997.

[24] Effendi, Onong Uchayana, Ilmu Komunikasi Teori dan Praktek, cet. IV Bandung: Remaja Karya, 2010.

[25] E.M, M. Abdul Ghoffer dan al-Atsari, Abu Ihsan (Pentj), Tafsir Ibnu Katsir, Jilid 8, Bogor: Pustaka Imam Asy Syafii, 2004.

[26] Fahmi, Abu Bakar, Mencerna Situs Jejaring Sosial. Jakarta: PT Elex Media Komputindo, 2011.

[27] Fiddler, Roger. Mediamorfosis, Yogyakarta: Bentang Budaya, 2003.

[28] Fiske, John, Pengantar Ilmu Komunikasi. Jakarta: Rajawali Pers, 2012.

[29] Gregory, Sam \& Gillian Caldwell. Video for Change: Panduan Video untuk Advokasi.Yogyakarta: Insist Press, 2008.

[30] Hadari, Nawawi. Instrumen Penelitian Bidang Sosial, Yogyakarta: Gajah Mada University Press, 1996.

[31] Hafidhuddin, Didin. Dakwah Aktual, Cet.I; Jakarta: Gema Insani Press, 1998.

[32] Halim, Abdul. Sejarah Perjuangan KH. Abdul Wahab, Bandung: Baru, 1970.

[33] Hamid, Farid dan Heri Budianto (ed).Ilmu Komunikasi Sekarang dan Tantangan Masa Depan.Jakarta: Kencana Prenada Media Group, 2011

[34] Hatta, Mohd. Dakwah Kontemporer; Analisis Gerakan Dakwah Al-Ikhwan Al Muslimun.Bandung: Ciptapustaka Media, 2007.

[35] Hasmy, A. Dustur Dakwah menurut al-Qur'an, Jakarta: Bulan Bintang, 1997. 
[36] Hefni, Harjani. Komunikasi Islam, Jakarta: Prenadamedia Group, 2015.

[37] Ilmu Pengetahuan Populer, Jilid 2, Jakarta: PT Widyadara, 1994, hlm. 180

[38] Kamus Besar Bahasa Indonesia, edisi ketiga, Jakarta: Balai Pustaka, 2007.

[39] Khallaf, Abdul Wahab, Ilmu Ushul Fiqih, cet. I, Semarang: Toha Putra Group, 1994.

[40] Kholil, Syukur. Komunikasi Islam Bandung: Cipta Pustaka, 2007.

[41] Kholil, Syukur (edit).Teori Komunikasi Massa. Bandung: Ciptapustaka, 2011.

[42] Kota Medan Dalam Angka 2016, Badan Pusat Statistik Kota Medan

[43] Kriyantono, Rachmat.Teknik Praktis Riset Komunikasi, cetakan ke 5 Jakarta: Prenada, 2010.

[44] Kristi, E. Poerwandari, Metode Penelitian Sosial Jakarta : Universitas Terbuka, 1998.

[45] Liliweri, Alo. Komunikasi Serba Ada Serba Makna, Jakarta: Prenada Media Group, 2011.

[46] Lubis, M Solly. Filsafat Ilmu dan Penelitian.Bandung: Mandar Maju, 1994.

[47] Mandzur, Ibnu, Lisan al-Arab, Beirut: Dar Shadir, 1412/1992.

[48] Ma’ruf, Moeh Thaha, Pedoman Pemimpin Pergerakan, Jakarta: PBNU, 1954.

[49] Mastori, Pemikiran Politik Dakwah Kontemporer, Yogyakarta: Deepublish, 2005.

[50] Moleong, Lexy J., Metodologi Penelitian Kualitatif, Bandung: Remaja Rosda Karya, 2000

[51] Mulyana, Deddy, Ilmu Komunikasi Suatu Pengantar, Bandung: PT Remaja Rosdakarya, 2007.

[52] Muhammad, Fadil Ibnu, Dakwah Online, Jakarta: Mizania, 2014.

[53] Munawwir, Ahmad Warson. Al-Munawwir Kamus Arab-Indonesia, Surabaya: Pustaka Progesif, 1997.

[54] Morrisan, Teori Komunikasi Individu Hingga Massa, Jakarta: Kencana Prenada Media Group, 2013.

[55] Nasrullah, Rully. Teori dan Riset Media Siber (Cybermedia) Jakarta: Prenadamedia Group, 2014.

[56] Nasution, Harun. Islam Ditinjau dari Beberapa Aspek, Jilid I, Jakarta: UI Press, 1979.

[57] Nugraha, Tuhu.WWW.HM Defining Your Digital Strategy.Jakarta: Upnormals Publishing, 2014.

[58] Pawito, Penelitian Komunikasi Kualitatif, Yogyakarta: LkiS, 2007.

[59] Poerwadarminta, W.J.S. Kamus Umum Bahasa Indonesia, edisi ketiga, Jakarta: Balai Pustaka, 2003.

[60] Qutub, Sayyid, Khâsaais Tashawuru-l-Islâm, Beirut:Dâru al-Qur'ân al-Karîm, 1978.

[61] Rakhmat, Jalaluddin. Metode Penelitian Kualitatif, cet. Kedua (Bandung: PT Remaja Rosda Karya, 2006

[62] Romli, Asep Syamsul M. Komunikasi Dakwah, Bandung: RomelteaMedia, 2013.

[63] Rohim, Syaiful. Teori Komunikasi; Perspektif, Ragam dan Aplikasi, Jakarta: Rineka Cipta, 2016.

[64] Ruben, Brent D. dan . Stewart, Lea P. Komunikasi dan Perilaku Manusia Jakarta: Rajawali Pers, 2013.

[65] Saputra, Wahidin. Pengantar Ilmu Dakwah, Jakarta: Rajawali Pers, 2011.

[66] Sanusi, Shalahudin pembahasan disekitar prinsip-prinsip dakwah Islam Semarang: Ramadhani, 1964.

[67] Sevilla, Consuelo G. dkk., Pengantar Metode Penelitian, cet.1, Jakarta: Penerbit UI Press, 2006.

[68] Sitompul, Azhar. Dakwah Islam \& Perubahan Sosial, Bandung: Citapustaka Media Perintis, 2009.

[69] Suprapto, Tommy. Pengantar Teori dan Manajemen Komunikasi Yogyakarta: MedPress, 2009.

[70] Suhariyanto, Budi, Tindak Pidana Teknologi Informasi (Cybercrime) Jakarta: Rajawali Pers, 2012.

[71] Sugiyono. Cara Mudah Menyusun Skripsi, Tesis, dan Disertasi. Bandung: Alfabeta, 2013.

[72] Sulianta, Feri. Keajaiban Sosial Media, Jakarta: Elex Media Komputindo, 2015.

[73] Sunggono, Bambang. Metode Penelitian Hukum. Jakarta; PT RajaGrafindo Persada,1997.

[74] Yunus, Mahmud. Pedoman Dakwah Islamiyah, Jakarta: Hidakarya Agung, 1965.

[75] Yusuf, Yunan, et. al., Ensiklopedi Muhammadiyah, Jakarta: RajaGrafindo, 2005.

[76] Webster's New Encyclopedic Dictionary, New York: Black Dog and Leventhan Publ. Inc, 1994.

[77] Wiryanto, Pengantar Ilmu Komunikasi, cet. II, Jakarta: PT Grasindo, 2005.

[78] @ mrbambang, Instagram Handbook; Tip Fotografi Ponsel, Jakarta: Mediakita, 2012.

[79] @Osolihin, Sosmed Addict; Kecanduan yang Tak Perlu, Jakarta: Gema Insani, 2015.

[80] Ratna Sari Silalahi, "Hubungan Penggunaan Teknologi Informasi Internet dengan Presyasi Belajar Remaja di SMA Negeri 1 Longkikis” Jurnal, eJournal Ilmu Komunikasi, Volume 1, Nomor 1, 2013.

[81] Gubrium, Jaber F and James A. Holstein, 1992. "Qualitative Methods", dalam Encyclopedia of Sociology, Vol. 3. New York: Macmillan Publishing Company.

[82] Rusli Nasrullah, "Konstruksi Identitas Muslim di Media Baru", Komunika, Jurnal Dawah STAIN Purwokerto, Vol. 5, No. 2 ( Juli - Desember 2011.

[83] Salbiah Siregar, Nahdlatul Ulama (NU) di Medan (Studi Tentang Sejarah dan Peran Sosial Keagamaan Dari 1950-2010)". Master tesis, Pascasarja IAIN Sumatera Utara

[84] http://id.wikipedia.org/wiki/Komputer

[85] http://id.wikipedia.org/wiki/Sejarah_Internet

[86] http://kbbi.web.id/daya

[87] https://id.wikipedia.org/wiki/Media_sosial

[88] https://id.wikipedia.org/wiki/Jejaring_sosial

[89] http://id.wikipe dia.org/wiki/Prita_Mulyasari

[90] http://id.wikipedia.org/wiki/Youtube 